\title{
Marketing Behavior of Banana Grower in Bhagalpur District of Bihar
}

\author{
Priyanka Kumari ${ }^{1 *}$ and M.K. Wadhwani ${ }^{2}$ \\ ${ }^{1}$ Department of Agricultural Economics, Dr. Rajendra Prasad Central Agricultural University, Pusa, Samastipur, Bihar, India \\ ${ }^{2}$ Department of Agricultural Economics, Bihar Agricultural University, Sabour, Bhagalpur, Bihar, India \\ "Corresponding author: priyankajee27@gmail.com
}

\begin{abstract}
The study was conducted on primary data, collected from a sample of 60 banana growers, consisted of $26(43 \%), 25(42 \%)$ and $9(15 \%)$ marginal \& small, semi-medium and medium \& large category. The data were collected from the sample growers with the help of specifically prepared pre-tested schedules through Survey Method by interviewing them, selected through Multi-Stage Sampling Technique from a cluster of 3 villages of Nawgachhia block of Bhagalpur district. The growers in general (76.67\%) were found selling banana in 'local market'. The semi-medium and medium \& large category (36.0 and 56.0 per cent) growers were also found selling it to 'distant markets'. The 'contract sale' was pre-dominantly prevailed as 'mode of sale' in the area. The 'cash sale' as-well-as 'credit sale' was prevailing in the area. The marginal \& small category growers sold banana to the pre-harvest contractors.
\end{abstract}

Keywords: Multi-Stage Sampling Technique, local market, distant markets, contract sale, Pre-harvest contractors

India is the first rank in Banana production in the world. Banana is the most delicious fruit used as subsidiary food in all over the world. It is consumed as the table and culinary fruit. It contains almost all the essential nutrients and is used in several medicines. Realizing the importance of fruit cultivation many farmers are diverting their resources towards plantation of fruit crops. Area under fruit crops is, therefore, increasing day by day. As a diet it is easy to digest, nearly fat free, rich source of carbohydrates with calorific value of $67 \mathrm{~g}$ per $100 \mathrm{~g}$ of fruit and is free from sodium, making it a salt free diet (Singh, 2007).

Its cultivation is distributed throughout the warmer countries and is confined regions between 30 degree $\mathrm{N}$ and 30 degree $\mathrm{S}$ of the equator. It is also called paradise of fruits. India account for over 18 per cent (16.81 M.T.) of global banana products and ranks first in India. It accounts for over 35 per cent of total area under the fruit crops is the country. In India, banana is well adopted in the region varying from humid tropics to humid sub-tropics and semi arid- tropics and from the sea level up to an elevation of 2000 meter above mean sea level. Availability of huge genetic diversity, varying production system, its suitability to wide range of agro-climatic condition is attributed for its large scale adoption. It is grown as homestead garden as well as commercial plantation. Commercial production system is largely irrigated while subsistence cultivation is rain-fed farming.

In Bihar state, there are two distinct banana growing areas viz. old Vaishali region and new North- Eastern (Kosi) region, both of the regions are endowed with congenial climatic conditions favorable for growth and development of banana. It is an important source of income for small aswell-as large farmer who produce it either on small or large areas.

Recently, the demand for banana is increasing and area under the crop in the state has undergone large expansion is last 20 years. Though banana was introduced in this region during late seventies, 
the pace of adoption was very fast during eighties and today this belt produces nearly two-third of total banana in the state. Thana Bihpur in Khagaria and Nawgachhia in Bhagalpur and large area in Madhepura, Katihar, Purnea and Saharsa districts have now acquired special status in banana production in Kosi Region. Remaining one-third production comes from the old banana growing belt of Vaisahli and Samastipur district where tall cultivars are grown. It is being cultivated commercially in the districts of Muzaffarpur, Vaishali, Samastipur, Darbhanga, Madhepura and Katihar districts of North Bihar.

\section{Data Based and Methodology}

The present study was carried out with the objective of examining the marketing behavior of banana growers in Nawgachhia block of Bhagalpur district of the Bihar state. The study was primarily be based on primary data which had been collected from a Sample of 60 banana farmers selected on basis of the Multi-Stage Sampling Technique. Bhagalpur district has been selected on the basis of the highest quantity of banana production in the region. One block namely Nawgachhia of Bhagalpur district having a maximum area under Banana cultivation had been selected. From selected block, a cluster of 3 villages had been selected randomly from each of selected village, and sample of 20 banana growers were selected randomly.

\section{RESULTS AND DISCUSSION}

\section{Classification of sample banana growers}

The classification of sample banana grower is presented in Table 1. It reveals that the sample (60) includes 26 (43.33 per cent) of the marginal and small category of farmers, while semi- medium and medium \& large category includes 25 (41.67 per cent) and 9 (15.00 percent) respectively.

\section{Composition of farm family sample banana farmers}

The composition of the farm family had been presented in Table 2. It is found that the average size of the family of three categories of farm families was 9, 9 and 12 respectively. In terms of the sex-wise composition of the family, it includes 3 male members, while female and children member included 3 and 4 on an overall basis with a total number of members as 10 .

\section{Marketing behavior of banana grower}

The marketing is the most important business activity which influences the overall profitability of any production activity including banana production. As such marketing behavior of banana, growers was analyzed and had been presented in Table 3. The table indicates that all three categories of growers uses to sell banana in 'local market'.

Table 1: Classification of sample banana farmers

\begin{tabular}{|c|c|c|c|}
\hline \multirow{2}{*}{ Category of banana growers } & \multirow{2}{*}{ Operational holding (ha) } & \multicolumn{2}{|c|}{ Study Sample } \\
\hline & & No. & Percentage \\
\hline Marginal \& Small & $<2.0$ ha & 26 & 43.33 \\
\hline Semi-Medium & $2.0-4.0$ ha & 25 & 41.67 \\
\hline Medium \&Large & $>4.0$ ha & 09 & 15.00 \\
\hline \multicolumn{2}{|c|}{ Total } & 60 & 100.00 \\
\hline
\end{tabular}

Table 2: Average family size of the sample households

\begin{tabular}{ccccc}
\hline $\begin{array}{c}\text { Category of banana } \\
\text { grower }\end{array}$ & Male & Female & Children & Overall \\
\hline Marginal \& Small $\left(\mathrm{n}_{1}=26\right)$ & $3(33.33)$ & $2(22.22)$ & $4(44.45)$ & $9(100.00)$ \\
Semi-Medium $\left(\mathrm{n}_{2}=25\right)$ & $3(33.33)$ & $3(33.33)$ & $3(33.33)$ & $9(100.00)$ \\
Medium \& Large $\left(\mathrm{n}_{3}=9\right)$ & $4(33.33)$ & $4(33.33)$ & $4(33.33)$ & $12(100.00)$ \\
\hline Total $(\mathrm{n}=\mathbf{6 0})$ & $\mathbf{3 ( 3 0 . 0 0 )}$ & $\mathbf{3 ( 3 0 . 0 0 )}$ & $\mathbf{4 ( 4 0 . 0 0 )}$ & $\mathbf{1 0}(\mathbf{1 0 0 . 0 0 )}$ \\
\hline
\end{tabular}

Note: Figures in parenthesis indicates percentage to the total. 
Table 3: Marketing behavior of banana grower

\begin{tabular}{ccccccc}
\hline \multirow{2}{*}{$\begin{array}{c}\text { Category of banana } \\
\text { grower }\end{array}$} & \multicolumn{2}{c}{ Choice of Market } & \multicolumn{2}{c}{ Mode of Sale } & \multicolumn{2}{c}{ Method of Sale } \\
\cline { 2 - 6 } & Local & $\begin{array}{c}\text { Both } \\
\text { (Local \& Distant) }\end{array}$ & $\begin{array}{c}\text { Contract } \\
\text { Sale }\end{array}$ & $\begin{array}{c}\text { Both (Contract \& } \\
\text { Direct Sale }\end{array}$ & Cash Sale & $\begin{array}{c}\text { Both (Cash \& Credit } \\
\text { Sale) }\end{array}$ \\
\hline $\begin{array}{c}\text { Marginal \& Small } \\
\left(\mathrm{n}_{1}=26\right)\end{array}$ & $26(100.00)$ & $0(0.00)$ & $26(100.00)$ & $0(0.00)$ & $26(100.00)$ & $0(0.00)$ \\
Semi-Medium $\left(\mathrm{n}_{2}=25\right)$ & $16(64.00)$ & $09(36.00)$ & $16(64.00)$ & $09(36.00)$ & $09(36.00)$ & $16(64.00)$ \\
Medium \& Large $\left(\mathrm{n}_{3}=9\right)$ & $04(44.44)$ & $05(55.55)$ & $04(44.44)$ & $05(55.55)$ & $05(55.56)$ & $04(44.44)$ \\
Overall $(\mathrm{n}=60)$ & $46(76.67)$ & $14(23.33)$ & $46(76.67)$ & $14(23.33)$ & $40(66.67)$ & $20(33.33)$ \\
\hline
\end{tabular}

Note: Figure in brackets shows per cent.

Table 4: Reason of selling banana to different market functionaries

\begin{tabular}{ccccc}
\hline Market functionaries & \multicolumn{4}{c}{ Category of banana farmers } \\
\cline { 2 - 5 } & $\begin{array}{c}\text { Marginal \& Small } \\
\left(\mathbf{n}_{\mathbf{1}}=\mathbf{2 6}\right)\end{array}$ & $\begin{array}{c}\text { Semi-Medium } \\
\left(\mathbf{n}_{\mathbf{2}}=\mathbf{2 5}\right)\end{array}$ & $\begin{array}{c}\text { Medium \& Large } \\
\left(\mathbf{n}_{\mathbf{3}} \mathbf{= 9 )}\right.\end{array}$ & $\begin{array}{c}\text { Overall } \\
(\mathbf{n}=\mathbf{6 0})\end{array}$ \\
\hline 1.Pre-harvest Contractor & & & & \\
\hline Easiest option available & $26(100.00)$ & $16(64.00)$ & $4(44.44)$ & $46(76.67)$ \\
No burden of transport & $26(100.00)$ & $16(64.00)$ & $4(44.44)$ & $46(76.67)$ \\
No commission charges & $26(100.00)$ & $16(64.00)$ & $4(44.44)$ & $46(76.67)$ \\
Long term practice & $26(100.00)$ & $16(64.00)$ & $4(44.44)$ & $46(76.67)$ \\
\hline 2. Commission Agent & & & & \\
\hline Availability & $0(0.00)$ & $09(36.00)$ & $5(55.56)$ & $14(23.33)$ \\
Credit need & $0(0.00)$ & $09(36.00)$ & $5(55.56)$ & $14(23.33)$ \\
Immediate Cash payment & $0(0.00)$ & $09(36.00)$ & $5(55.56)$ & $14(23.33)$ \\
Long term practice & $0(0.00)$ & $09(36.00)$ & $5(55.56)$ & $14(23.33)$ \\
\hline
\end{tabular}

Note: Figure in parenthesis shows per cent to total.

The semi-medium and medium \& large category (36.0 and 56.0 per cent) growers were also found selling it to 'distant markets'. The 'contract sale' was predominantly prevailed as 'mode of sale' in the area. About 36.0 per cent of semi-medium and 56.0 per cent of medium \& large category growers also found direct selling their produce/banana. As-far-as method of sale was concerned 'cash sale' as-well-as 'credit sale' was prevailing in the area. The marginal \& small farmers preferred to sale against cash, while semi-medium and medium \& large farmers preferred both sale against cash $(36.0$ \& 56.0 per cent) as-well-as credit (64.0 and 45.0 per cent). On overall basis, it was found the grower preferred of selling banana in the local market (76.67 per cent).

The table indicates that all three categories of growers used to sell banana in local market. The semi-medium and medium \& large category growers to the level of 36.0 and 56.0 percent also sold to 'distant markets'. The 'contract sale' was predominantly prevailing as mode of sale in the area. Nearly 36.0 per cent semi-medium and 56.0 per cent of medium \& large category grower also found direct selling the produce. As-far-as 'method of sale' is concerned 'cash sale' as-well-as 'credit sale' was prevailed in the area. The marginal \& small farmers preferred to sale against cash, while semi-medium and medium \& large growers preferred both sale against cash (36.0 \& 56.0 per cent) and credit (64.0 and 45.0 per cent).

\section{Selection of market functionaries}

The banana growers were also investigated about the selection of market functionaries, i.e. either pre-harvest contractors or commission agents. The results had been presented in Table 4 . The table indicates that all the marginal \& small farmers sold their produce to the pre-harvest contractors while 64 per cent semi-medium and 44 per cent medium \& large category sold to pre-harvest contractors. 
As far as marketing through commission agent is concerned 36.0 percent of semi-medium and 56.0 per cent of medium \& large growers were found selling banana through them. This may be due to more quantity of marketable surplus with them as compared to marginal \&small category growers.

\section{CONCLUSION}

Banana being heavy feeder and labour intensive nature of crop, Banana, in study area is grown mainly under perennial monoculture system under assured irrigation. The usual economic life of plantation is 1-3 years, which means one planted crop and two ratoon crops. But the growers could hardly take $2^{\text {nd }}$ ratoon crop successfully due to one or other reason. The predominance of pre-harvest contractors restricts the growers to harvest benefits of scale of production and due to large number of marginal \& small un-organized banana growers marketing linkages have not yet developed and stabilized. After repealing of APMC Act (since 2006) no alternate marketing method has been developed/ implemented in the state. The farmers are forced to sell their produce through contractors/traders due to their inability in marketing activity.

\section{Marketing behavior of banana growers}

- All three category of growers found to sell banana in 'local market'. The semi-medium and medium \& large category (36.0 and 56.0 per cent) growers were also found selling it to 'distant markets'.

- The 'contract sale' was pre-dominantly prevailed as 'mode of sale' in the area. About 56.0 per cent of medium \& large and 36.0 per cent of semimedium category growers also found direct selling their produce/banana.
- As-far-as method of sale is concerned 'cash sale' as-well-as 'credit sale' was prevailing in the area. The marginal \& small farmers preferred to sale against cash, while semi-medium and medium \& large farmers preferred both, sale against cash (36.0 \& $56.0 \%)$ as-well-as credit (64.0 and $45.0 \%$ ). On overall basis it was found that the grower preferred to sell banana in local market $(76.67 \%)$

- All the marginal \& small category growers sold banana to the pre-harvest contractors while 64 per cent semi-medium and 44 per cent medium \& large category sold to pre-harvest contractors.

- As far as marketing through commission agent is concerned 36.0 percent of semi-medium and 56.0 per cent of medium \& large category growers were found selling banana through them. This may be due to more quantity of marketable surplus with them as compared to marginal \&small category growers.

\section{REFERENCES}

Azad, C.K. and Sikka, B.K. 1991. Production and marketing of temperate fruits in North West Region of India. Acta Horticulture, 270: 67-74.

Mehta, R. and Srivastava, P.K. 2000. Analysis of seasonality in prices of Agricultural Commodities Agricultural Situation in India, 57(4): 311-314.

Sarswat, S.P. 1999. An economic analysis of production and marketing of apple in Himachal Pradesh, The Bihar Journal of Agricultural Marketing, 7(3): 320-328.

Selvin, J.N. and Radhakrishnan, V. 1990. Marketing of banana in Kerala. Indian Journal of Horticulture, 47(3): 225-330.

Vigneshwara, V. 1988. Marketing of banana in India. Indian Journal of Marketing 18(8-10): 29-30. 